\title{
Commentary: Useful little trick
}

\author{
Jacob R. Miller, MD, and Pirooz Eghtesady, MD, PhD
}

\author{
From St Louis Children's Hospital, Washington University School of Medicine, St Louis, Mo. \\ Disclosures: Authors have nothing to disclose with regard to commercial support. \\ Received for publication May 19, 2019; accepted for publication May 21, 2019; available ahead of print July 10 , \\ 2019. \\ Address for reprints: Pirooz Eghtesady, MD, PhD, St Louis Children's Hospital, One Children's Place, Suite $5 \mathrm{~S}$, \\ St Louis, MO 63110 (E-mail: eghtesadyp@wustl.edu). \\ J Thorac Cardiovasc Surg 2020;159:e83-4 \\ $0022-5223 / \$ 36.00$ \\ Copyright (c) 2019 by The American Association for Thoracic Surgery \\ https://doi.org/10.1016/j.jtcvs.2019.05.024
}

Not long ago, the senior author (P.E.) was having a conversation with Professor Ivan Rebeyka regarding "little tricks" that surgeons use but do not publish. Dr Rebeyka shared a story about how Dr Norwood used such a trick when operating to increase his efficiency. He would take a couple of bites and then, with his pick-ups, hold the tissue down and pull on the sutures to tighten the suture line, not spending as much time pulling up the follow after every bite. These little tricks can be useful to the craft of surgery and are not captured in the published literature.

In this issue of the Journal, Kang and colleagues ${ }^{1}$ offer such a trick. They provide a practical description to aid in safely obtaining arterial access for cardiac catheterization for infants on venoarterial extracorporeal membrane oxygenation (ECMO). Often, in part because of the ease of access, the femoral route is chosen for cardiac catheterization in these sick patients, although this choice is not without its associated risks. Despite the risks, for pediatric patients supported by ECMO, when a cardiac catheterization is necessary, it can be performed successfully with an acceptable complication rate. ${ }^{2,3}$

Having an alternative method for arterial access, however, in what are undoubtedly very sick infants, would be a very useful adjunct. Kang and colleagues ${ }^{1}$ describe 3 cases in which infant cardiac catheterization was conducted through the arterial cannula while the patient was on ECMO support by connecting a Y-shaped connector with a hemostatic valve to the arterial limb of the ECMO cannula. Similar techniques have been described in adult patients with the femoral arterial cannula. ${ }^{4,5}$ Further, this technique has been used in pediatric patients, again through the femoral arterial cannula. ${ }^{6}$ Kang and colleagues ${ }^{1}$ describe the first utilization of this technique with a similar set of adapters in neonates and small infants who are cannulated through the carotid artery. Although their report is similar to other, Kang and colleagues ${ }^{1}$ notably demonstrate the safety of this technique in children less than $5 \mathrm{~kg}$ in weight. In addition, the position of the arterial cannula in the right common carotid artery provided a favorable angle for select procedures (eg, intervention on

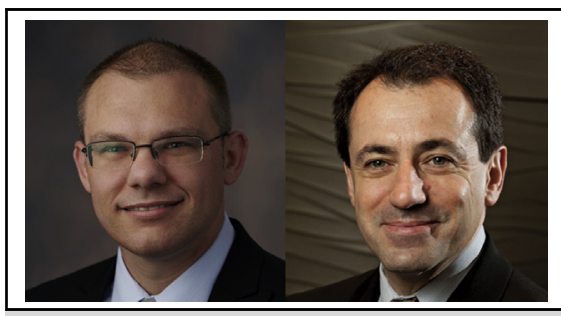

Jacob R. Miller, MD (left), and Pirooz Eghtesady, MD, $\mathrm{PhD}$ (right)

\section{Central Message}

Cardiac catheterizations performed on infants can be difficult, even more so if the patient is supported by ECMO. With some ingenuity, a carotid arterial cannula can be used for arterial access.

See Article page e79.

systemic-to-pulmonary arterial shunts or associated branch pulmonary arteries, assessment of coronary arteries). Theoretically, their methodology could be adapted for other situations, such as central cannulation. Similarly, access on the venous side could be obtained, although this would introduce the risk of air embolism.

Although this article may not represent the first time that this has been successfully performed, or even described, Kang and colleagues ${ }^{1}$ do provide an excellent resource for others planning to use this technique. What it may lack in originality, it makes up for in practicality. Kang and colleagues $^{1}$ expound nicely on possible uses and provide a nice video to describe the technical details, ever important for the clinician who may want to apply this methodology.

\section{References}

1. Kang SL, Lee KJ, Stanisic A, Chaturvedi RR. Using the arterial cannula for cardiac catheterization in neonates and small infants supported by extracorporeal membrane oxygenation. J Thorac Cardiovasc Surg. 2020;159:e79-81.

2. Abraham BP, Gilliam E, Kim DW, Wolf MJ, Vincent RN, Petit CJ. Early catheterization after initiation of extracorporeal membrane oxygenation support in children is associated with improved survival. Catheter Cardiovasc Interv. 2016;88: 592-9.

3. Boscamp NS, Turner ME, Crystal M, Anderson B, Vincent JA, Torres AJ. Cardiac catheterization in pediatric patients supported by extracorporeal membrane oxygenation: a 15-year experience. Pediatr Cardiol. 2017;38:332-7.

4. Endemann DH, Philipp A, Hengstenberg C, Luchner A, Pühler T, Hilker M, et al A simple method of vascular access to perform emergency coronary angiography in patients with veno-arterial extracorporeal membrane oxygenation. Intensive Care Med. 2011;37:2046-9. 
5. Ücer E, Fredersdorf S, Jungbauer C, Debl K, Philipp A, Amann M, et al. A unique access for the ablation catheter to treat electrical storm in a patient with extracorporeal life support. Europace. 2014;16:299-302.
6. Thuys C, MacLaren G, d'Udekem Y, Eastaugh L. Vascular access for pediatric coronary angiography on extracorporeal membrane oxygenation. World J Pediatr Congenit Heart Surg. 2015;6:126-9. 